\title{
Interspecific and intraspecific variation in leaf toughness of Arctic plants in relation to habitat and nutrient supply
}

\author{
Ned Fetcher, Sofia Iglesia, Stephen J. Turner, and Thomas C. Parker
}

\begin{abstract}
Leaf toughness is an important functional trait that confers resistance to herbivory and mechanical damage. We sought to determine how species composition, climate, seasonality, and nutrient availability influence leaf toughness in two types of tundra in northern Alaska. We measured leaf toughness as force to punch for 11 species of Arctic plants in tussock tundra and dry heath tundra at 17 sites distributed along a latitudinal gradient. Rubus chamaemorus L. and the graminoids occupied opposite ends of the leaf toughness spectrum, with Rubus chamaemorus requiring the least force to punch, whereas one of the graminoids, Eriophorum vaginatum L., required the most. Leaf toughness increased with mean summer temperature for Eriophorum vaginatum and Betula nana L., whereas it declined with warmer temperatures for the other species. Toughness of mature leaves of Eriophorum vaginatum did not vary through the growing season but declined significantly after senescence. Application of $\mathrm{N}$ and $\mathrm{P}$ fertilizer in an experimental site decreased leaf toughness in three species but had no effect on four others. Leaf toughness of four out of five species in dry heath was greater than for the same species in tussock tundra, but there was no difference in community-weighted mean toughness between tussock tundra and dry heath.

Key words: leaf toughness, Arctic tundra, intraspecific variation, Eriophorum vaginatum, latitudinal gradient.

Résumé : La dureté des feuilles est un trait fonctionnel important qui confère une résistance à l'herbivorie et aux dommages mécaniques. Les auteurs ont cherché à déterminer comment la composition des espèces, le climat, la saisonnalité et la disponibilité des nutriments influencent la dureté des feuilles dans deux types de toundras du nord de l'Alaska. Ils ont mesuré la dureté des feuilles en tant que de force nécessaire pour les perforer, chez 11 espèces de plantes arctiques dans la toundra à touradon et la toundra de lande sèche sur 17 sites répartis le long d'un gradient latitudinal. Rubus chamaemorus L. et les graminoïdes occupaient les extrémités opposées du spectre de la dureté des feuilles, Rubus chamaemorus exigeant le moins de force pour perforer, tandis qu'un des graminoïdes,
\end{abstract}

Received 12 May 2020. Accepted 28 January 2021.

N. Fetcher. Institute for Environmental Science and Sustainability, Wilkes University, Wilkes-Barre, PA 18766, USA.

S. Iglesia.* Dr. Phillip Frost Department of Skin Biology and Dermatological Sciences, University of Miami Hospital, 1295 N.W. 14th St., Suite K-M, Miami, FL 33136, USA.

S.J. Turner.** Department of Environmental Engineering and Earth Science, Wilkes University, Wilkes-Barre, PA 18766, USA.

T.C. Parker. Biological and Environmental Sciences, School of Natural Sciences, University of Stirling, Stirling, FK 94LA, Scotland, UK.

Corresponding author: Ned Fetcher (e-mail: ned.fetcher@wilkes.edu).

${ }^{1}$ This paper is part of a Special Issue entitled: Impacts of climate change on tundra ecosystems: Three decades of results from the International Tundra Experiment (ITEX).

*Present address: Aventura, FL, USA.

${ }^{* *}$ Present address: Borton-Lawson, 613 Baltimore Dr., Suite 300, Wilkes-Barre, PA 18702, USA.

Copyright remains with the author(s) or their institution(s). This work is licensed under a Creative Attribution 4.0 International License (CC BY 4.0) http://creativecommons.org/licenses/by/4.0/deed.en_GB, which permits unrestricted use, distribution, and reproduction in any medium, provided the original author(s) and source are credited. 
Eriophorum vaginatum L., en exigeait le plus. La dureté des feuilles augmente avec la température moyenne de l'été chez Eriophorum vaginatum et Betula nana L., alors qu'elle diminue avec des températures plus élevées chez les autres espèces. La dureté des feuilles matures d'Eriophorum vaginatum ne variait pas au cours de la saison de croissance, mais diminuait de manière significative après la sénescence. L'application d'engrais à $\mathrm{N}$ et $\mathrm{P}$ sur un site expérimental diminuait la dureté des feuilles de trois espèces, mais n'avait aucun effet sur quatre autres. La dureté des feuilles de quatre des cinq espèces de la lande sèche était supérieure à celle des mêmes espèces de la toundra à touradon, mais il n'y avait aucune différence dans la dureté moyenne pondérée de la communauté entre la toundra à touradon et la lande sèche. [Traduit par la Rédaction]

Mots-clés : dureté des feuilles, toundra arctique, variation intraspécifique, Eriophorum vaginatum, gradient latitudinal.

\section{Introduction}

Surveys of plant traits such as plant height and specific leaf area have great potential to provide insight into the functioning of Arctic ecosystems and inform predictions of their response to climate change (Bjorkman et al. 2018a; Myers-Smith et al. 2019). Functional traits associated with leaves affect rates of photosynthesis and decomposition, whereas traits associated with plant stature can affect canopy height and leaf area index, all of which can impact carbon storage (Myers-Smith et al. 2019). Belowground traits such as rooting depth can influence the acquisition of nitrogen (Hewitt et al. 2019). Functional traits are likely to be influenced by many factors associated with climate change, including increased air temperatures, greater depth of thaw, increased growing seasons, and decreased snow cover (Bjorkman et al. 2018a; Iturrate-Garcia et al. 2020; Niittynen et al. 2020) and, as such, they can be used to understand and predict biosphere feedbacks to climate change (Myers-Smith et al. 2011).

Leaf toughness is an important functional trait that can affect plant performance as well as ecosystem functioning. Leaf toughness, as measured by punching with a penetrometer (Onoda et al. 2011), is a composite of several properties, including shear and compressive strength, fracture toughness, which is defined as the resistance to their propagation of cracks, and the size of the area tested (Vincent 1992, cited in Sanson et al. 2001). Nevertheless, it has been shown to be a useful measure of resistance to herbivory (Feeny 1970; Coley 1983; Sanson et al. 2001). Studies have shown that leaf toughness discourages herbivory (Lucas et al. 2000; Sanson 2006; Read and Stokes 2006), perhaps as a consequence of increased cellulose (Kitajima et al. 2016). Increased leaf toughness should help leaves that are exposed to strong winds resist bending, torsion, deformation, and ultimately breakage, although this attribute has been examined less than the relationship between leaf toughness and herbivory. In a study of Plantago major L., Anten et al. (2010) found that wind did not affect leaf toughness as much as mechanical stimulation. However, the more exposed conditions found in many Arctic habitats may play a greater role in selecting for leaf toughness than in the lawns and pastures favored by Plantago major. At the ecosystem level, leaf toughness can affect rates of decomposition (Cornelissen et al. 1999; Pérez-Harguindeguy et al. 2000). In an extensive review, Onoda et al. (2011) examined interspecific trends in leaf toughness in response to latitudinal, temperature, and precipitation gradients. They did not find a significant trend with respect to latitude or temperature, but they did find that leaf toughness increased with decreasing mean annual precipitation. However, their survey did not include species from the Arctic. By contrast, studies of functional traits in the Arctic have not included measures of leaf toughness (Bjorkman et al. 2018a, 2018b).

Nevertheless, leaf toughness may be a significant trait for Arctic plants. Below-freezing temperatures and limited light mean that tundra vegetation is inactive throughout the 
winter, although growth proceeds rapidly once snow disappears (Khorsand Rosa et al. 2015). During the winter, leaves of evergreen species are exposed to high winds and blowing snow. Species that grow in exposed heath habitats are particularly stressed during winter due to low snow cover. Growth is limited due to low nutrients associated with mainly organic soils (Chapin and Shaver 1985). To some extent, plants can ameliorate these harsh conditions by growing low and close together to resist the effects of wind and blowing snow. As plant height increases with warming temperatures (Bjorkman et al. 2018a), two groups of plants would be expected to show increased leaf toughness. Graminoid leaves would require greater stiffness to support themselves, whereas leaves of evergreen shrubs would be exposed to higher wind speeds and more blowing snow.

Rapid change in Arctic ecosystems and resulting changes to plant communities are likely to change leaf toughness across the tundra biome. The expected increase in Arctic temperature by $2-3^{\circ} \mathrm{C}$ in the winter and $1{ }^{\circ} \mathrm{C}$ in the summer (Chapman and Walsh 2007) could have regional and global implications leading to increased decomposition rates of organic matter within frozen soil and a deeper active layer. If more nutrients are made available as a consequence (Mack et al. 2004; Hewitt et al. 2020), leaf toughness may be altered, as faster growth may be favored over the production of structural compounds. By contrast, the ecosystem feedbacks from climate change are complex (Wookey et al. 2009), and each may influence leaf toughness in different ways. Therefore, it is important that we systematically assess leaf toughness in relation to a variety of different environmental factors to project its change into the future.

We address the following questions: (1) How does leaf toughness vary between common tundra plants? (2) Is there latitudinal, seasonal, or yearly variation in leaf toughness? (3) Is there a difference in leaf toughness between tussock tundra and dry heath? (4) Is there a difference in community-weighted mean toughness between vegetation types? (5) What is the effect of added nutrients on leaf toughness? (6) How much does intraspecific variation contribute to variation in leaf toughness within communities?

\section{Materials and methods}

\section{Study design}

Leaves were collected from 16 different locations in northern Alaska in two Arctic vegetation types: tussock tundra and dry heath (Table 1). Tussock tundra consists of 15-25 cm diameter tussocks of Eriophorum vaginatum L. growing in peaty soils at a density of 4-7 tussocks $/ \mathrm{m}^{2}$, with evergreen and deciduous shrubs, mosses, and lichens growing in and between the tussocks (Wein 1973; Fetcher and Shaver 1982). Dry heath consists mostly of very small evergreen and deciduous shrubs and is found on exposed ridges and fell fields with rocky soils with a very thin surface layer of organic soil (Shaver and Chapin 1991). Samples of fully developed leaves were collected on three occasions: in June 2015, from June 2016 until mid-September 2016, and in July 2017. Fifteen sites were sampled in tussock tundra and dry heath along a latitudinal gradient from $66^{\circ} \mathrm{N}$ to $70^{\circ} \mathrm{N}$. In addition to sites in undisturbed tussock tundra, we sampled a site in the Anaktuvuk Burn, which was a large fire that occurred in 2007 (Jones et al. 2009).

We examined the effect of species and climate on leaf toughness in tussock tundra (Questions 1 and 2) measured at twelve sites in late June and early July for five widely distributed species, Betula nana L., Carex bigelowii Torr. ex Schwein., Eriophorum vaginatum, Rhododendron tomentosum Harmaja, and Vaccinium vitis-idaea L. (Table 1). This analysis from twelve sites had only one deciduous species (B. nana). To include more deciduous species for purposes of comparison, we sampled three additional common species, Rubus chamaemorus L., Salix pulchra Cham., and Vaccinium uliginosum L., at three sites along with the five species listed above (Table 1). 
Table 1. Sites used for collection of leaf toughness data.

\begin{tabular}{|c|c|c|c|c|c|c|c|c|c|c|c|c|}
\hline Location & $\begin{array}{l}\text { Elevation } \\
(\mathrm{m})\end{array}$ & $\begin{array}{l}\text { Latitude } \\
\left({ }^{\circ} \mathrm{N}\right)\end{array}$ & $\begin{array}{l}\text { Mean June-July } \\
\text { Temperature }\left({ }^{\circ} \mathrm{C}\right)\end{array}$ & $\begin{array}{l}\text { Tussock } \\
\text { tundra }\end{array}$ & $\begin{array}{l}\text { Dry } \\
\text { heath }\end{array}$ & $\begin{array}{l}\text { Climate } \\
\text { analysis } \\
\text { five } \\
\text { species }\end{array}$ & $\begin{array}{l}\text { Climate } \\
\text { analysis } \\
\text { eight } \\
\text { species }\end{array}$ & $\begin{array}{l}\text { Seasonal } \\
\text { Variation }\end{array}$ & $\begin{array}{l}\text { Year to } \\
\text { year } \\
\text { variation }\end{array}$ & $\begin{array}{l}\text { Vegetation } \\
\text { type }\end{array}$ & $\begin{array}{l}\text { Nutrient } \\
\text { addition }\end{array}$ & $\begin{array}{l}\text { Intraspecific } \\
\text { variation }\end{array}$ \\
\hline No Name Creek & 171 & 66.1171 & 16.19 & $\mathrm{X}$ & - & $\mathrm{X}$ & - & - & - & - & - & $\mathrm{X}$ \\
\hline Gobbler's Knob & 487 & 66.7459 & 14.15 & $\mathrm{X}$ & - & $\mathrm{X}$ & - & - & - & - & - & $\mathrm{X}$ \\
\hline Coldfoot & 331 & 67.2589 & 14.75 & $\mathrm{X}$ & - & $\mathrm{X}$ & $\mathrm{X}$ & $\mathrm{X}$ & $\mathrm{X}$ & - & - & $\mathrm{X}$ \\
\hline Timberline & 749 & 68.0300 & 9.05 & $\mathrm{X}$ & - & $\mathrm{X}$ & - & - & - & - & - & $\mathrm{X}$ \\
\hline Chandalar & 992 & 68.0518 & 8.83 & $\mathrm{X}$ & $\mathrm{X}$ & $\mathrm{X}$ & - & - & - & $\mathrm{X}$ & - & $\mathrm{X}$ \\
\hline Atigun Pass & 1466 & 68.1302 & - & - & $\mathrm{X}$ & - & - & - & - & $\mathrm{X}$ & - & $\mathrm{X}$ \\
\hline Atigun Camp & 1062 & 68.173 & 8.26 & $\mathrm{X}$ & - & $\mathrm{X}$ & - & - & - & $\mathrm{X}$ & - & $\mathrm{X}$ \\
\hline Galbraith & 826 & 68.4961 & 10.22 & $\mathrm{X}$ & - & - & - & - & $\mathrm{X}$ & - & - & $\mathrm{X}$ \\
\hline Toolik Lake & 760 & 68.6292 & 10.66 & $\mathrm{X}$ & $\mathrm{X}$ & $\mathrm{X}$ & $\mathrm{X}$ & $\mathrm{X}$ & $\mathrm{X}$ & $\mathrm{X}$ & $\mathrm{X}$ & $\mathrm{X}$ \\
\hline Toolik Fertilized & 760 & 68.6242 & 10.66 & $\mathrm{X}$ & - & - & - & - & - & - & $\mathrm{X}$ & - \\
\hline Kuparuk & 761 & 68.6486 & 10.58 & $\mathrm{X}$ & - & $\mathrm{X}$ & - & - & - & - & - & $\mathrm{X}$ \\
\hline Dust Site & 841 & 68.6690 & 10.49 & $\mathrm{X}$ & - & $\mathrm{X}$ & - & - & - & - & - & $\mathrm{X}$ \\
\hline MS121 & 411 & 68.8765 & 11.72 & $\mathrm{X}$ & - & $\mathrm{X}$ & - & - & - & - & - & $\mathrm{X}$ \\
\hline Anaktuvuk Burn & 348 & 68.9968 & $10.86^{*}$ & $\mathrm{X}$ & - & - & - & - & $\mathrm{X}$ & - & - & - \\
\hline Happy Valley & 333 & 69.1394 & 10.58 & $\mathrm{X}$ & - & $\mathrm{X}$ & - & - & - & - & - & $\mathrm{X}$ \\
\hline Sagwon & 300 & 69.4244 & 11.14 & $\mathrm{X}$ & $\mathrm{X}$ & $\mathrm{X}$ & $\mathrm{X}$ & $\mathrm{X}$ & $\mathrm{X}$ & $\mathrm{X}$ & - & $\mathrm{X}$ \\
\hline
\end{tabular}

${ }^{*}$ Mean based on air temperature data from 2009-2016 (A. Rocha, personal communication, 2020). 
To determine seasonal and year-to-year variation (Question 2), we focused on Eriophorum vaginatum because it produces leaves at different times of the season. We sampled seasonal variation from early mid-June through mid-September at three sites (Table 1). At the end of the season (24 August 2016 - 15 September 2016), we compared leaf toughness of green and senesced leaves at Coldfoot, Toolik Lake, and Sagwon. To examine variation between 2015 and 2016, we used data collected from mid-June through mid-July at five sites (Table 1).

For comparing leaf toughness between vegetation types (Question 3), we used three sites that had both tussock tundra and dry heath vegetation (Table 1). A fourth dry heath site at Atigun Pass was paired with the nearby tussock tundra site at Atigun Camp for purposes of analysis.

To calculate community-weighted mean leaf toughness (Question 4), we used biomass values for tussock tundra and dry heath from a harvest that was carried out in 2006 by the Arctic Long-Term Ecological Research Project (Gough 2017). The tussock tundra site was $1.5 \mathrm{~km}$ from the site that we used to collect leaf toughness samples, whereas the dry heath site was $2.5 \mathrm{~km}$ away. Both sites had the same suite of species in similar proportions as the sites sampled for leaf toughness. All the aboveground tissue was clipped from ten $20 \mathrm{~cm} \times 20 \mathrm{~cm}$ quadrats in both tussock tundra and dry heath and sorted by species and tissue type. Tissues were dried at $65{ }^{\circ} \mathrm{C}$ and weighed to give biomass for each species in the quadrat. Leaf toughness values for species from tussock tundra and dry heath were multiplied by the biomass of the same species in a quadrat to calculate community-weighted mean leaf toughness for ten quadrats in each vegetation type. We did not have leaf toughness values for all of the species in the biomass samples. For tussock tundra the biomass of the missing species was a small percentage (5.9\%) of the total, whereas for dry heath, the biomass of missing species was a larger fraction (25\%) that consisted mostly of Empetrum nigrum L. and Loiseleuria procumbens (L.) Desv., the leaves of which were too small to be tested in our apparatus.

To determine the effects of added nutrients on leaf toughness (Question 5), we sampled tissue from an experimental site at Toolik Lake that was fertilized for 27 years with $10 \mathrm{~g} \mathrm{~m}^{-2} \mathrm{yr}^{-1}$ nitrogen and $5 \mathrm{~g} \mathrm{~m}^{-2} \mathrm{yr}^{-1}$ phosphorous and compared it with a control site that was part of the same experiment. The experiment used a randomized block design with four blocks.

To determine abundance-weighted interspecific and intraspecific trait variance variation (Question 6) in leaf toughness (de Bello et al. 2011; Siefert et al. 2015), we used data from tussock tundra and dry heath at Toolik Lake, as that was the only site with abundance data. To determine the partitioning of variance between site, species, and population (Messier et al. 2010), for tussock tundra, we used data from 13 sites and eight species, whereas for dry heath we used data from four sites and eight species. (Table 1).

\section{Sample processing}

We sampled one leaf from all the species from the list in Table 2 that could be found in an area with a $1.5 \mathrm{~m}$ radius. For Eriophorum vaginatum, three tillers per tussock were collected. Once the first set of samples was gathered, we moved $5 \mathrm{~m}$ to the next sampling area to avoid gathering replicate genotypes. To sample the population of each species at each site, we obtained ten individual leaf samples, which were immediately stored in a plastic ziplock bag with a moist towel to prevent desiccation.

Samples were processed no longer than $2 \mathrm{~h}$ after collection. A penetrometer with a strain gauge (Imada, Inc., Northbrook, Illinois, USA, Model DS2-11) and a punch and die of $2 \mathrm{~mm}$ was used to measure the force to puncture the leaf avoiding the midrib, except for leaves that were so small that the midrib could not be avoided. The maximum force to punch $\left(F_{p}\right)$ for each sample was recorded. Leaf toughness can be expressed by the maximum 
Table 2. Species sampled in each vegetation type for leaf toughness measurements.

\begin{tabular}{|c|c|c|c|}
\hline Species & Growth Form & Tussock Tundra & Dry Heath \\
\hline Carex bigelowii Torr. ex Schwein. & Graminoid & $\mathrm{x}$ & $\mathrm{x}$ \\
\hline Eriophorum vaginatum L. & Graminoid & $\mathrm{x}$ & - \\
\hline Arctous alpina (L.) Niedenzu & Deciduous* shrub & - & $\mathrm{x}$ \\
\hline Dryas octopetala L. & Evergreen shrub & - & $\mathrm{x}$ \\
\hline Rhododendron tomentosum Harmaja & Evergreen shrub & $\mathrm{x}$ & $\mathrm{x}$ \\
\hline Vaccinium vitis-idaea $\mathrm{L}$. & Evergreen shrub & $\mathrm{x}$ & $\mathrm{x}$ \\
\hline Betula nana L. & Deciduous shrub & $\mathrm{x}$ & $\mathrm{x}$ \\
\hline Salix pulchra Cham. & Deciduous shrub & $\mathrm{x}$ & $\mathrm{x}$ \\
\hline Vaccinium uliginosum $\mathrm{L}$. & Deciduous shrub & $\mathrm{x}$ & - \\
\hline Rubus chamaemorus L. & Deciduous shrub & $\mathrm{x}$ & - \\
\hline Polygonum bistorta L. & Forb & - & $\mathrm{x}$ \\
\hline
\end{tabular}

*Leaves senesce in autumn, but are retained through the winter (Huryn and Hobbie 2012).

force required to punch the leaf divided by the circumference of the punch (L) (Onoda et al. 2011). The leaves of Eriophorum vaginatum were less than $2 \mathrm{~mm}$ wide $(0.4 \mathrm{~mm}-1.3 \mathrm{~mm})$, so an optical comparator was used to gauge the width. To determine the length of leaf tissue that was punched, we calculated the length of the two chords subtended by the width as given by the formula $4 \times$ arcsine(width/2). Raw data are available in the TRY database (https:// www.try-db.org) under the names Leaf Toughness of Alaskan Arctic Plants in Undisturbed Tundra and Leaf Toughness of Alaskan Arctic Plants in Fertilized Tundra.

\section{Statistical analyses}

We used the JMP package (SAS Institute Inc 2019) to perform analysis of covariance with mean temperature from 1977 through 2017 for June and July downloaded from the SNAP (2018) data archive (https://uaf-snap.org/get-data) as a measure of the environment that combined differences in latitude with differences in elevation (Questions 1 and 2). The model for both the five-species and eight-species analyses was

$$
F_{p} / L_{i j}=S_{i}+T_{j}+S_{i} T_{j}+e_{i j}
$$

where $F_{p} / L_{i j}$ is leaf toughness of species $i$ at site $j, S_{i}$ is species $i$, and $T_{j}$ is temperature at site $j$. $F_{p} / L$ was log-transformed to stabilize the variance over a broad range of leaf toughness.

Linear regression with day of the year as an independent variable was used to evaluate changes in leaf toughness of Eriophorum vaginatum at Coldfoot, Toolik, and Sagwon during the growing season of 2016 (Question 2). The analysis was performed on each site separately. To determine the effect of leaf senescence on leaf toughness, we used two-way analysis of variance (ANOVA) with site and green vs. senesced as factors. We also used two-way ANOVA with site and year as factors to evaluate differences in leaf toughness between 2015 and 2016. Tukey's HSD test was used to determine differences at each site between green and senesced leaves and between 2015 and 2016. ANOVA tables are available as Supplementary File $S 1^{1}$.

To determine the effect of vegetation type (Question 3), we used two-way ANOVA with site and vegetation type as factors to analyze the response of leaf toughness for the graminoid $C$. bigelowii, the evergreens Rhododendron tomentosum and V. vitis-idaea, and the deciduous B. nana and S. pulchra, which were the species that were found in both site types. To compare community-weighted mean toughness for tussock tundra and dry heath at Toolik Lake (Question 4), we used a $t$ test assuming unequal variances.

\footnotetext{
${ }^{1}$ Supplementary material is available with the article at https://doi.org/10.1139/as-2020-0016.
} 
To analyze the effect of fertilization on leaf toughness of seven species of tussock tundra (Question 5), we used a randomized block ANOVA with fertilizer as a fixed effect and block as a random effect.

The community-weighted means at Toolik Lake were also used to estimate intraspecific vs. interspecific variation within communities (wITV), according to the variance partitioning approach of de Bello et al. (2011) that takes into account the relative abundance of species.

To estimate the partitioning of variation in leaf toughness in tussock tundra between site, species, and population within species and site (Question 6), we used variance component analysis with the varcomp procedure from the ape package in $\mathrm{R}(\mathrm{R}$ Development Core Team 2016) to analyze the log-transformed data (Messier et al. 2010; Umaña and Swenson 2019). We used a bootstrap procedure to estimate $95 \%$ confidence intervals by resampling our data set of the 1210 observations 700 times.

\section{Results}

\section{Variation between species and sites}

Most of the variation was explained by differences in species, with the graminoid Eriophorum vaginatum having the greatest values for leaf toughness, followed by the evergreen $V$. vitis-idaea, the graminoid $C$. bigelowii, the evergreen Rhododendron tomentosum, and the deciduous B. nana. In addition, there was a significant $(p<0.001)$ interaction between June-July temperature and leaf toughness of different species (Fig. 1). Leaf toughness of Eriophorum vaginatum and B. nana increased significantly $(p<0.0001)$ with increasing temperature, whereas that of the other species did not change significantly.

We sampled additional deciduous species at three sites, No Name Creek, Toolik Lake, and Sagwon. Eriophorum vaginatum had the toughest leaves, followed by V. vitis-idaea (Table 3). Rhododendron tomentosum and C. bigelowii had similar values for leaf toughness, whereas the four deciduous species had the lowest values (Table 4). There was considerable variation in the deciduous group, with $V$. uliginosum having almost twice the mean toughness as Rubus chamaemorus (Table 3).

In the dry heath, two evergreen species, $V$. vitis-idaea and Rhododendron tomentosum, had the toughest leaves along with $C$. bigelowii (Table 4). The leaves of the other evergreen species, Dryas octopetala L., were not as tough as V. vitis-idaea and Rhododendron tomentosum.

\section{Variation through season}

We found no significant change over the growing season in Eriophorum vaginatum until the leaves started to senesce in August. Green leaves at Coldfoot were significantly (Tukey's HSD, $p<0.05)$ tougher than senesced leaves $\left(5.63 \mathrm{kN} \mathrm{m}^{-1} \mathrm{vs.} 4.73 \mathrm{kN} \mathrm{m}^{-1}\right)$. At Sagwon and Toolik Lake, there was no difference.

\section{Variation between years}

Leaf toughness of Eriophorum vaginatum at the Anaktuvuk Burn increased from $3.66 \mathrm{kN} \mathrm{m}^{-1}$ in 2015 to $5.00 \mathrm{kN} \mathrm{m}^{-1}$ in 2016 (Tukey's HSD, $p<0.05$ ), whereas it did not change significantly at the other sites, Sagwon, Coldfoot, Galbraith, and Toolik Lake.

\section{Variation between vegetation types}

Leaf toughness was lower in tussock tundra than in dry heath for all species except for Rhododendron tomentosum (Fig. 2). For C. bigelowii and S. pulchra, there was a significant interaction $(p<0.05)$ between site and vegetation type, but in all cases, the tussock tundra type had a lower value than the corresponding dry heath value.

Although some species appear to have greater toughness in dry heath than in tussock tundra, this does not address the question of whether community-weighted mean leaf 
Fig. 1. $\log _{10}$ leaf toughness measured as force to punch divided by punch circumference $\left(F_{p} / L\right)\left(\mathrm{kN} \mathrm{m}^{-1}\right)$ for five species of tussock tundra as a function of mean June-July temperature along a latitudinal gradient in northern Alaska. Untransformed values are on the right-hand side of the figure. Eriophorum vaginatum $(\triangle,---)$, Vaccinium vitis-idaea (×,---), Carex bigelowii (V, ---), Rhododendron tomentosum $(\square,-)$, Betula nana $(*, \cdots)$.

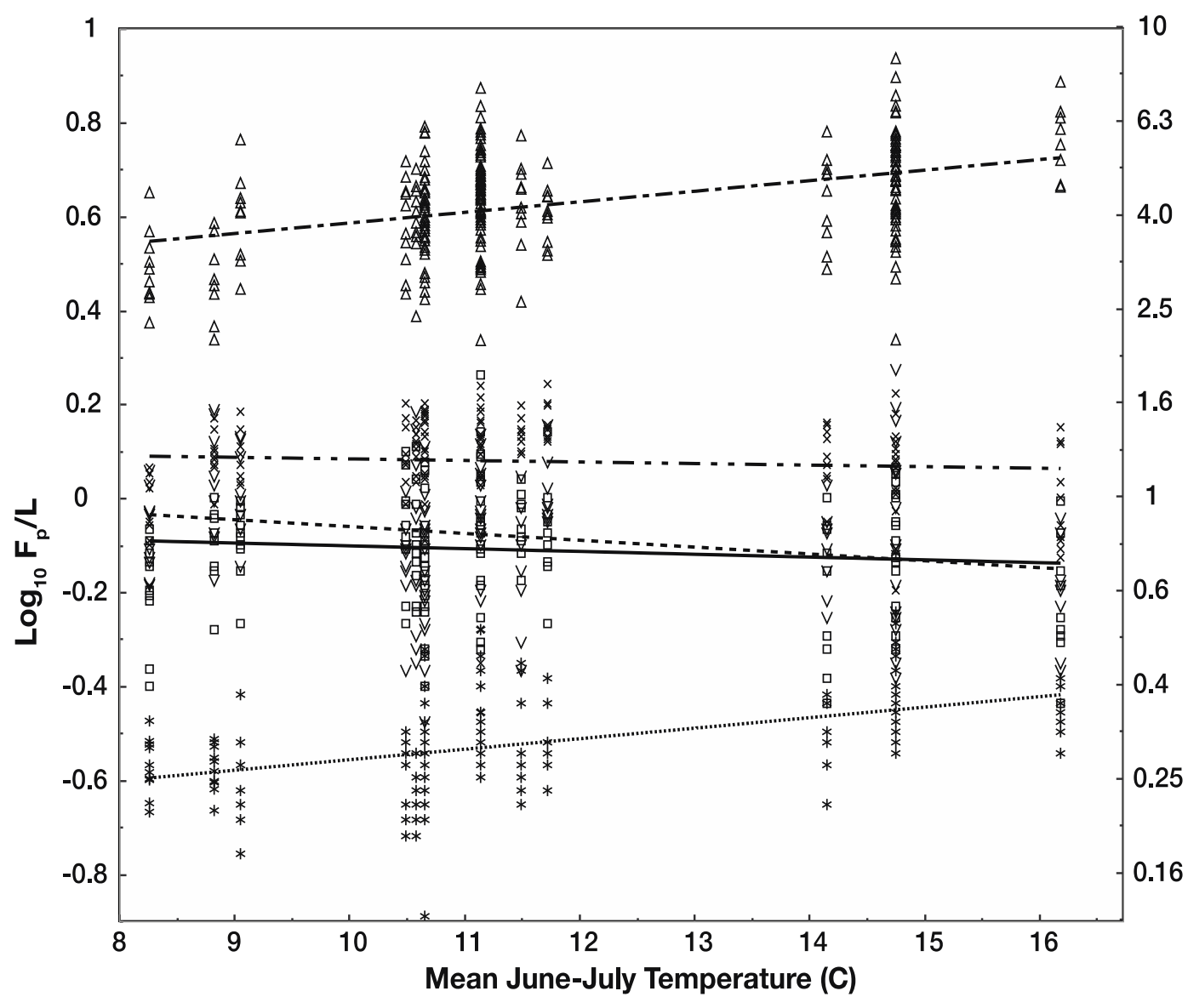

Table 3. Mean of $\log _{10}$ leaf toughness measured as force to punch divided by punch circumference $\left(F_{p} / L\right)$ $\left(\mathrm{kN} \mathrm{m}^{-1}\right)$ for eight species of tussock tundra at three sites in Alaska.

\begin{tabular}{lccccccc}
\hline Species & N & Mean & $\begin{array}{l}\text { Standard } \\
\text { error }\end{array}$ & $\begin{array}{l}\text { Lower } \\
95 \% \text { CI }\end{array}$ & $\begin{array}{l}\text { Upper } \\
95 \% \text { CI }\end{array}$ & $\begin{array}{l}\text { Back transformed } \\
\text { mean }\end{array}$ & HSD \\
\hline Eriophorum vaginatum & 120 & 0.644 & 0.009 & 0.626 & 0.663 & 4.41 & $\mathrm{~A}$ \\
Vaccinium vitis-idaea & 50 & 0.061 & 0.020 & 0.021 & 0.101 & 1.15 & $\mathrm{~B}$ \\
Carex bigelowii & 50 & -0.110 & 0.019 & -0.148 & -0.073 & 0.78 & $\mathrm{C}$ \\
Rhododendron tomentosum & 50 & -0.125 & 0.021 & -0.167 & -0.082 & 0.75 & $\mathrm{C}$ \\
Vaccinium uliginosum & 40 & -0.352 & 0.024 & -0.400 & -0.304 & 0.45 & $\mathrm{D}$ \\
Salix pulchra & 50 & -0.467 & 0.020 & -0.508 & -0.427 & 0.34 & $\mathrm{EF}$ \\
Betula nana & 50 & -0.494 & 0.015 & -0.524 & -0.464 & 0.32 & $\mathrm{~F}$ \\
Rubus chamaemorus & 40 & -0.576 & 0.025 & -0.626 & -0.526 & 0.27 & \\
\hline
\end{tabular}

Note: CI, confidence interval; HSD, Tukey’s Honestly Significant Difference $(p<0.05)$. 
Table 4. Mean of $\log _{10}$ leaf toughness measured as force to punch divided by punch circumference $\left(\mathrm{kN} \mathrm{m}^{-1}\right)$ for eight species of dry heath tundra at Toolik Lake and Sagwon in Alaska.

\begin{tabular}{lccccccc}
\hline Species & N & Mean & $\begin{array}{l}\text { Standard } \\
\text { error }\end{array}$ & $\begin{array}{l}\text { Lower } \\
\text { 95\% CI }\end{array}$ & $\begin{array}{l}\text { Upper } \\
\text { 95\% CI }\end{array}$ & \multicolumn{2}{c}{$\begin{array}{l}\text { Back transformed } \\
\text { mean }\end{array}$} \\
\hline Vaccinium vitis-idaea & 30 & 0.112 & 0.019 & 0.074 & 0.149 & 1.29 & HSD \\
Carex bigelowii & 40 & 0.036 & 0.016 & 0.004 & 0.068 & 1.09 & $\mathrm{~A}$ \\
Rhododendron tomemtosum & 30 & -0.135 & 0.019 & -0.173 & -0.098 & 0.73 & $\mathrm{~B}$ \\
Dryas octopetala & 30 & -0.265 & 0.019 & -0.303 & -0.228 & 0.54 & $\mathrm{D}$ \\
Salix pulchra & 40 & -0.353 & 0.016 & -0.386 & -0.321 & 0.44 & $\mathrm{D}$ \\
Polygonum bistorta & 39 & -0.363 & 0.017 & -0.395 & -0.330 & 0.43 & $\mathrm{DE}$ \\
Arctous alpina & 20 & -0.372 & 0.023 & -0.417 & -0.326 & 0.42 & $\mathrm{DE}$ \\
Betula nana & 30 & -0.437 & 0.019 & -0.475 & -0.400 & 0.36 & $\mathrm{E}$ \\
\hline
\end{tabular}

Note: CI, confidence interval; HSD, Tukey’s Honestly Significant Difference $(p<0.05)$.

Fig. 2. Leaf toughness measured as force to punch divided by punch circumference $\left(F_{p} / L\right)\left(\mathrm{kN} \mathrm{m}^{-1}\right)$ for five species found in both tussock tundra and dry heath tundra. ${ }^{*}, p<0.05 ;{ }^{* * *}, p<0.001$.

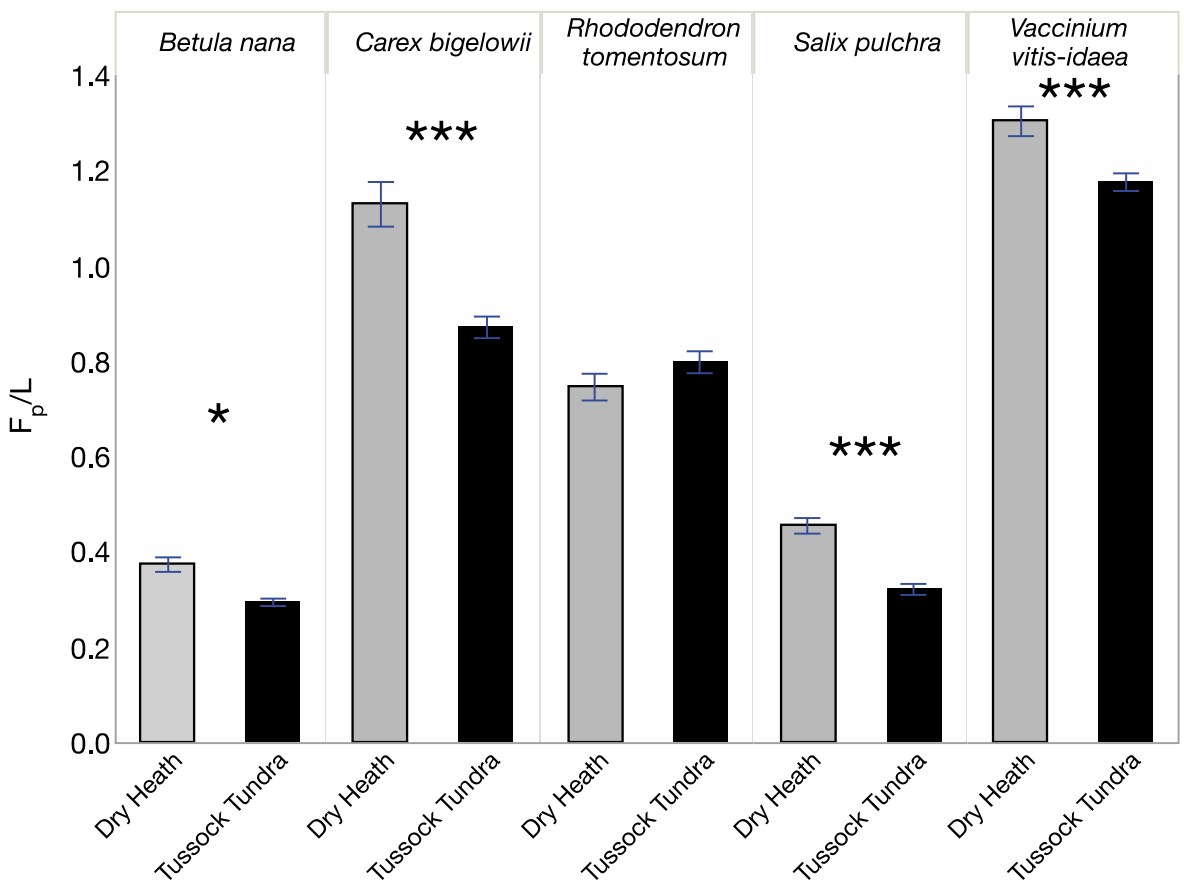

toughness is different between the two vegetation types. There was no significant difference between mean toughness in tussock tundra and dry heath (Fig. 3), but variance was much higher in tussock tundra due to the presence of Eriophorum vaginatum in some quadrats but not others.

\section{Effect of nutrient addition}

Fertilization with nitrogen and phosphorous affected the species differently. There was no significant difference between fertilized and unfertilized plots for B. nana, Eriophorum vaginatum, Rhododendron tomentosum, and Rubus chamaemorus (Table 5). By contrast, leaf toughness of $C$. bigelowii, $V$. vitis-idaea, and S. pulchra was significantly lower in the fertilized plot (Table 5). 
Fig. 3. Community-weighted mean leaf toughness based on ten sample quadrats per vegetation type and measured as force to punch divided by punch circumference $\left(F_{p} / L\right)\left(\mathrm{kN} \mathrm{m}^{-1}\right)$ for dry heath and tussock tundra vegetation at Toolik Lake, Alaska.

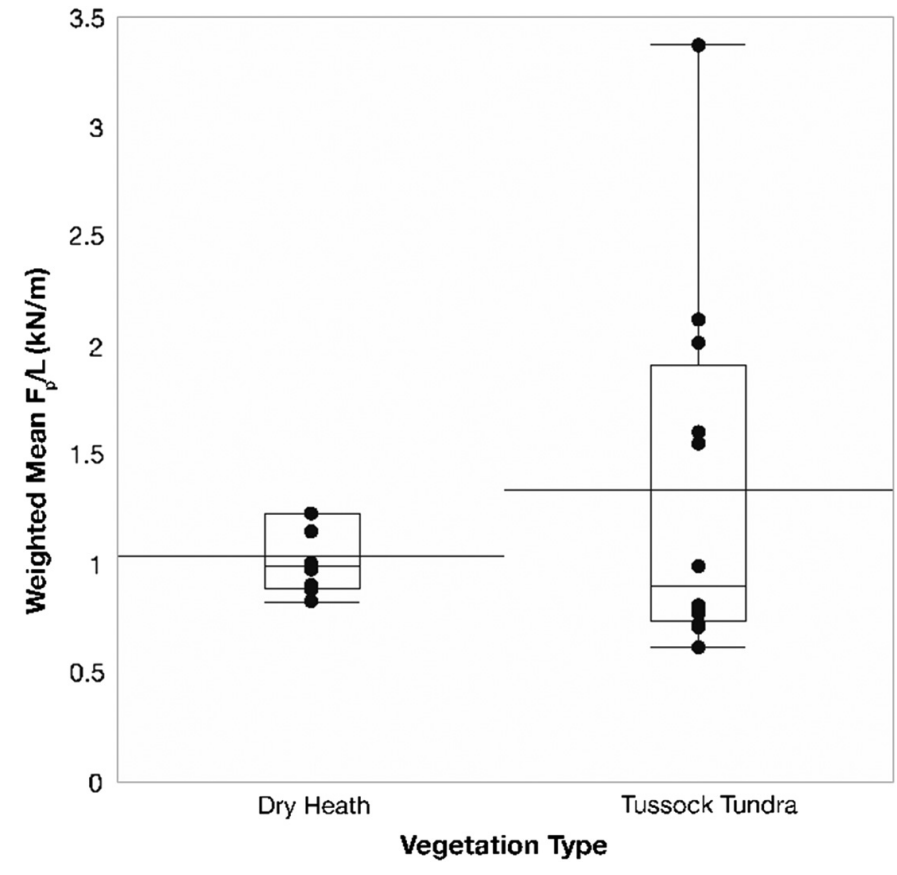

Table 5. Leaf toughness measured as force to punch divided by punch circumference $\left(\mathrm{kN} \mathrm{m}^{-1}\right)$ as affected by fertilization with nitrogen $(\mathrm{N})$ and phosphorus $(\mathrm{P})$ for seven species of tussock tundra.

\begin{tabular}{llllll}
\hline Species & $\begin{array}{l}\text { Mean of } \\
\text { control }\end{array}$ & $\begin{array}{l}\text { Standard error } \\
\text { of control }\end{array}$ & $\begin{array}{l}\text { Mean of NP } \\
\text { fertilization }\end{array}$ & $\begin{array}{l}\text { Standard error } \\
\text { of NP fertilization }\end{array}$ & $p$ \\
\hline Eriophorum vaginatum & 3.774 & 0.111 & 3.785 & 0.111 & $\mathrm{~ns}$ \\
Vaccinium vitis-idaea & 1.315 & 0.027 & 1.086 & 0.035 & $<0.0001$ \\
Carex bigelowii & 0.909 & 0.028 & 0.664 & 0.028 & $<0.0001$ \\
Rhododendron tomentosum & 0.845 & 0.035 & 0.754 & 0.035 & $\mathrm{~ns}$ \\
Salix pulchra & 0.264 & 0.008 & 0.215 & 0.011 & $<0.001$ \\
Rubus chamaemorus & 0.242 & 0.016 & 0.255 & 0.016 & $\mathrm{~ns}$ \\
Betula nana & 0.231 & 0.010 & 0.243 & 0.010 & $\mathrm{~ns}$ \\
\hline
\end{tabular}

Note: ns, not significant.

\section{Interspecific versus intraspecific variation in leaf toughness}

wITV in tussock tundra was $8.4 \%$ of the total variation, whereas in dry heath it was $9.2 \%$, and the mean over both communities was $8.8 \%$. The analysis of variance components for tussock tundra found that the variance within populations was less than in dry heath (Table 6). For tussock tundra, the proportion of the variance that was due to populations within species was almost the same as the proportion due to species. Results for dry heath were similar, although the proportions were smaller, as there was more variation within populations. For both vegetation types, the proportion due to site was $0 \%$. 
Table 6. Variance partitioning of $\log _{10}$ leaf toughness measured as force to punch divided by punch circumference $\left(\mathrm{kN} \mathrm{m}^{-1}\right)$ for eight species of tussock tundra distributed across 13 sites and four species of dry heath across four sites.

\begin{tabular}{lccc}
\hline Variance Component & Proportion of Variance & $2.5 \%$ Quantile & $97.5 \%$ Quantile \\
\hline Tussock tundra & & & \\
Site & $0.00 \%$ & $0.00 \%$ & $0.00 \%$ \\
Species & $46.25 \%$ & $45.51 \%$ & $47.05 \%$ \\
Population & $46.15 \%$ & $45.49 \%$ & $47.06 \%$ \\
Within & $7.60 \%$ & $5.87 \%$ & $8.98 \%$ \\
Dry heath & & \\
Site & $0.00 \%$ & $0.00 \%$ & $0.00 \%$ \\
Species & $40.47 \%$ & $37.69 \%$ & $44.63 \%$ \\
Population & $40.51 \%$ & $37.70 \%$ & $44.62 \%$ \\
Within & $19.02 \%$ & $10.75 \%$ & $24.61 \%$ \\
\hline
\end{tabular}

\section{Discussion}

We found that leaf toughness in common plants of the Low Arctic varied across several axes. Most of the variation was between species, with Eriophorum vaginatum requiring more than five times the force per unit length than Rubus chamaemorus. Leaves of evergreen species were tougher than deciduous species. In this respect, the general pattern of leaf toughness follows the leaf economics spectrum (Wright et al. 2004), although the fit is imperfect. For example, the graminoids, Eriophorum vaginatum and $C$. bigelowii, had some of the toughest leaves, even though the leaves senesce and die back in the fall. Furthermore, there was considerable variation within the evergreen group; leaves of $V$. vitis-idea were considerably tougher than those of Rhododendron tomentosum.

As the Arctic warms, deciduous shrubs are expected to become a larger component of the vegetation (Tape et al. 2006; Myers-Smith et al. 2011; Myers-Smith and Hik 2018). Thus, we can expect a community-level trend towards less tough leaves as deciduous shrubs increase, especially if they replace graminoids. Changes in community leaf toughness could have effects at higher trophic levels. Eriophorum vaginatum and $C$. bigelowii are among the toughest of the measured plants and contain higher amounts of biogenic silica than most other tundra species (Carey et al. 2017), which deters herbivory (Massey et al. 2007, 2009). Further, B. nana is highly favored by insect herbivores (Belsing 2015; Metcalfe et al. 2019), whereas S. pulchra is favored by caribou (White and Trudell 1980). Therefore, changes in plant community composition could affect herbivory through changes in community leaf toughness.

Environmental factors, including site temperature, vegetation type, and site fertilization also contributed to variation. For most of the species that we studied, leaf toughness declined with increasing site temperature, which is consistent with the findings of Onoda et al. (2011) and Kandlikar et al. (2018). However, leaf toughness of Eriophorum vaginatum and Rubus chamaemorus increased with site temperature. Leaves of Eriophorum vaginatum south of the timberline are longer than those farther north (Shaver et al. 1986; Fetcher and Shaver 1990), so the additional toughness may be a consequence of having to maintain the leaves erect.

It is not surprising that leaf toughness did not vary through the growing season as once a leaf is developed, it is not likely to change characteristics until senescence. Year-to-year variation was not significant, except for the Anaktuvuk Burn site. The beginning of the growing season on the North Slope in 2015 was much warmer than in 2016 (Parker et al. 2017). Because the Anaktuvuk Burn site was completely burned in 2007 (Jones et al. 2009), Eriophorum vaginatum is growing more vigorously there even though the mean temperature 
in June and July is similar to that of Toolik Lake (Table 1). Colder temperatures in June may have reduced the rate of leaf expansion at the beginning of the growing season, thereby producing tougher leaves.

As the landscape becomes more dominated by shrubs and leaf toughness declines, decomposition rates may increase. Leaves of the species with one of the lowest values for toughness in our study, B. nana, had the highest rates of decomposition in a study carried out in tussock tundra at Toolik Lake (McLaren et al. 2017). It was followed by Rhododendron tomentosum, V. vitis-idaea, and Eriophorum vaginatum, in that order, which is the inverse of their ranking in leaf toughness (Fig. 1, Table 3). This pattern seems to hold for other ecosystems as well. Leaf tensile strength was negatively correlated with loss of litter mass for the plants of various life forms, including herbaceous dicots, woody dicots, and graminoid monocots from both Argentina and Great Britain (Cornelissen et al. 1999). This pattern was also found for leaf toughness as measured by a penetrometer and the rate of decomposition of leaves of tropical trees in the Malaysian rain forest (Kurokawa and Nakashizuka 2008). By contrast, both evergreen and deciduous shrubs contain substantial amounts of woody tissue, which decomposes slowly. Thus, increases in shrub biomass may lead to an increase in the proportion of woody tissue and a reduction in community-weighted mean rates of decomposition (Hobbie 1990).

Individual species had tougher leaves in the dry heath than in the tussock tundra. Plants in the heath are more exposed to wind and abrasion by blowing snow and, thus, may benefit from having tougher leaves. The community-weighted mean was not different, however, because of the presence of Eriophorum vaginatum in the tussock tundra. Not only did it increase the variance, but it raised the overall mean for the community because it has the highest values for leaf toughness. Given the relationship between leaf toughness and decomposition, it seems reasonable to propose that mean decomposition rates might be similar in dry heath and tussock tundra.

In a warming Arctic, nutrients are generally considered to become more available (Mack et al. 2004; Schmidt et al. 2002; but see DeMarco et al. 2014). This may affect leaf toughness by increasing specific leaf area (Knops and Reinhart 2000). Fertilization experiments have resulted in increased productivity and biomass accumulation in tundra plants (Shaver and Chapin 1980). In our study, leaf toughness decreased after fertilization for three tundra species, whereas in four others, it was unaffected. In spinach, leaf toughness, as measured by a punch test, was negatively correlated with the amount of nitrogen provided, perhaps because the unfertilized leaves had smaller cells than the fertilized leaves (GutiérrezRodríguez et al. 2013). In a rainforest in Costa Rica, fertilized tree seedlings had lower leaf toughness than unfertilized plants as measured by a penetrometer in $20 \%$ shade but not in $2 \%$ shade (Nichols-Orians 1991). By contrast, fertilization did not affect leaf toughness of dogwood and tulip poplar seedlings growing in an old field and secondary forest in Georgia (Dudt and Shure 1994). By contrast, it increased toughness for alder (Alnus crispa (Aiton) Pursh) and poplar (Populus balsamifera L.) from interior Alaska, whereas it remained unchanged for willow (Salix alaxensis (Andersson) Coville) and birch (Betula papyrifera Marshall) (Irons et al. 1988). Although results vary from study to study, the general trend is for fertilization to decrease leaf toughness or leave it unaffected. Because the tundra is strongly nutrient limited (Shaver and Chapin 1980), increased nutrient availability is likely to reduce leaf toughness, at least for some species.

In the global meta-analysis by Siefert et al. (2015), the overall mean for wITV was $25 \%$. In our study, wITV for leaf toughness was less than $10 \%$, which is similar to the range reported for leaf length by Siefert et al. (2015), and much less than the value of $18 \%$ reported for the single study of leaf toughness in their survey. Thus, most of the variation in leaf toughness within a tundra plant community is due to differences between species. Such low values of 
wITV may result from a lack of plasticity in tundra plants as a consequence of adaptation to a stressful environment (Umaña and Swenson 2019).

Many Arctic plant species have extensive distributions, which often leads to trait variation between populations and local adaption that results in ecotypes (Fetcher and Shaver 1990; Bennington et al. 2012). The analysis of variance components showed that the species and population levels accounted for similar amounts of the total variance, whereas there was little variation due to the latitudinal gradient. This result was similar to that obtained for four of the seven traits studied by Umaña and Swenson (2019). In their study, leaf carbon content, leaf nitrogen content, ${ }^{13} \mathrm{~N}$, and leaf area showed little variation due to elevation and similar amounts due to species and population. The greater amount of variation due to population may be the result of plastic or genetic adjustment to local conditions (Umaña and Swenson 2019). The amount of the variance within populations was lower for tussock tundra than for dry heath, possibly reflecting lesser heterogeneity within the tussock tundra vegetation type as well as the large influence of Eriophorum vaginatum on leaf toughness.

Leaf toughness is measured less frequently than many other functional traits such as specific leaf area. Nevertheless, it integrates several structural and cellular traits with significant implications for understanding the ecosystem processes of herbivory and decomposition. Compared with many other traits, it requires relatively little effort and equipment, which argues for its inclusion in more investigations of functional traits.

\section{Acknowledgements}

We would like to thank Ian McMillan for advice on the design of the penetrometer and Mitch Adams for its construction. We thank Adrian Rocha for providing air temperature data for the Anaktuvuk Burn site. We would like to acknowledge Steven Unger for field assistance, two anonymous reviewers for helpful comments, and logistic support from the Toolik Field Station managed by the University of Alaska, Fairbanks, as well as the Arctic Long-Term Ecological Research project. Financial support for this research was provided through the National Science Foundation (NSF/PLR 1418010 and OISE-CNIC-1444192 to NF, NSF/PLR 1417645 to Michael L. Moody, and NSF/PLR 1417763 to Jianwu Tang).

\section{Author contributions}

NF, ST, SI, and TP designed the study, ST and SI collected the data, NF and SI wrote the manuscript, and all authors assisted in revising the final version.

\section{References}

Anten, N.P.R., Alcalá-Herrera, R., Schieving, F., and Onoda, Y. 2010. Wind and mechanical stimuli differentially affect leaf traits in Plantago major. New Phytol. 188: 554-564. doi: 10.1111/j.1469-8137.2010.03379.x. PMID: 20663062. Belsing, U. 2015. The survival of moth larvae feeding on different plant species in northern Fennoscandia. Lund University. Available from https://pdfs.semanticscholar.org/c637/57c6c75b78968ee508e199778fa0aa1c6280.pdf.

Bennington, C.C., Fetcher, N., Vavrek, M.C., Shaver, G.R., Cummings, K.J., and McGraw, J.B. 2012. Home site advantage in two long-lived arctic plant species: Results from two 30-year reciprocal transplant studies. J. Ecol. 100: 841-851. doi: 10.1111/j.1365-2745.2012.01984.x.

Bjorkman, A.D., Myers-Smith, I.H., Elmendorf, S.C., Normand, S., Rüger, N., Beck, P.S.A., et al. 2018a. Plant functional trait change across a warming tundra biome. Nature, 562: 57-62. doi: 10.1038/s41586-018-0563-7.

Bjorkman, A., Myers-Smith, I., Elmendorf, S., Normand, S., Thomas, H., Alatalo, J., et al. 2018b. Tundra Trait Team: A database of plant traits spanning the tundra biome. GEB Press, pp. 1402-1411. doi: 10.1111/geb.12821.

Carey, J.C., Parker, T.C., Fetcher, N., and Tang, J. 2017. Biogenic silica accumulation varies across tussock tundra plant functional type. Funct. Ecol. 31: 2177-2187. doi: 10.1111/1365-2435.12912.

Chapin, F.S., III., and Shaver, G.R. 1985. Individualistic growth response of tundra plant species to environmental manipulations in the field. Ecology, 66: 564-576. doi: 10.2307/1940405.

Chapman, W.L., and Walsh, J.E. 2007. Simulations of Arctic temperature and pressure by global coupled models J. Clim. 20: 609-32. doi: 10.1175/jcli4026.1. 
Coley, P.D. 1983. Herbivory and defensive characteristics of tree species in a lowland tropical forest. Ecol. Monogr. 53: 203-233. doi: $10.2307 / 1942495$.

Cornelissen, J.H.C., Pérez-Harguindeguy, N., Díaz, S., Grime, J.P., Marzano, B., Cabido, M., et al. 1999. Leaf structure and defence control litter decomposition rate across species and life forms in regional floras on two continents. New Phytol. 143: 191-200. doi: 10.1046/j.1469-8137.1999.00430.x.

de Bello, F., Lavorel, S., Albert, C.H., Thuiller, W., Grigulis, K., Dolezal, J., et al. 2011. Quantifying the relevance of intraspecific trait variability for functional diversity. Methods Ecol. Evol. 2(2): 163-174. doi: 10.1111/j.2041210x.2010.00071.x.

Demarco, J., Mack, M.C., and Bret-Harte, M.S. 2014. Effects of arctic shrub expansion on biophysical vs. biogeochemical drivers of litter decomposition. Ecology, 95: 1861-1875. doi: 10.1890/13-2221.1. PMID: 25163119.

Dudt, J.F., and Shure, D.J. 1994. The influence of light and nutrients on foliar phenolics and insect herbivory. Ecology, 75(1): 86-98. doi: 10.2307/1939385.

Feeny, P. 1970. Seasonal changes in oak leaf tannins and nutrients as a cause of spring feeding by winter moth caterpillars. Ecology, 51: 565-581. doi: 10.2307/1934037.

Fetcher, N., and Shaver, G.R. 1982. Growth and tillering patterns within tussocks of Eriophorum vaginatum. Holarctic Ecol. 5(2): 180-186. doi: 10.1111/j.1600-0587.1982.tb01034.x.

Fetcher, N., and Shaver, G.R. 1990. Environmental sensitivity of ecotypes as a potential influence on primary productivity. Am. Nat. 136: 126-131. doi: 10.1086/285085

Gough, L. 2017. Above ground plant and below ground stem biomass in the Arctic LTER dry heath tundra experimental plots, 2006, Toolik Lake, Alaska ver. 6. Environmental Data Initiative. doi: 10.6073/pasta/ 447aec542efb8fd505b85f90c35ea47e [accessed 14 November 2020].

Gutiérrez-Rodríguez, E., Lieth, H.J., Jernstedt, J.A., Labavitch, J.M., Suslow, T.V., and Cantwell, M.I. 2013. Texture, composition and anatomy of spinach leaves in relation to nitrogen fertilization. J. Sci. Food Agric. 93(2): 227-237. doi: 10.1002/jsfa.5780. PMID: 22806403.

Hewitt, R.E., Taylor, D.L., Genet, H., McGuire, A.D., and Mack, M.C. 2019. Below-ground plant traits influence tundra plant acquisition of newly thawed permafrost nitrogen. J. Ecol. 107: 950-962. doi: 10.1111/1365-2745.13062

Hewitt, R.E., DeVan, M.R., Lagutina, I.V., Genet, H., McGuire, A.D., Taylor, D.L., and Mack, M.C. 2020. Mycobiont contribution to tundra plant acquisition of permafrost-derived nitrogen. New Phytol. 226: 126-141. doi: 10.1111/ nph.16235. PMID: 31580482.

Hobbie, S.E. 1990. Temperature and plant species control over litter decomposition in Alaskan tundra. Ecol. Monogr. 66: 503-522. doi: 10.2307/2963492

Huryn, A., and Hobbie, J. 2012. Land of extremes: a natural history of the Arctic North Slope of Alaska. University of Alaska Press.

Irons, J.G., Oswood, M.W., and Bryant, J.P. 1988. Consumption of leaf detritus by a stream shredder: Influence of tree species and nutrient status. Hydrobiologia, 160(1): 53-61. doi: 10.1007/BF00014278.

Iturrate-Garcia, M., Heijmans, M., Cornelissen, J.H.C., Schweingruber, F., Niklaus, P., and Schaepman-Strub, G. 2020. Plant trait response of tundra shrubs to permafrost thaw and nutrient addition. Biogeosciences, 17: 4981-4998. doi: $10.5194 /$ bg-2019-498

Jones, B.M., Kolden, C.A., Jandt, R., Abatzoglou, J.T., Urban, F., and Arp, C.D. 2009. Fire behavior, weather, and burn severity of the 2007 Anaktuvuk River tundra fire, North Slope, Alaska. Arct. Antarct. Alp. Res. 41: 309-316. doi: 10.1657/1938-4246-41.3.309

Kandlikar, G.S., Vaz, M.C., Kriebel, R., Vargas, G., Michelangeli, F.A., Cordero, R., et al. 2018. Contrasting patterns of taxonomic, phylogenetic and functional variation along a Costa Rican altitudinal gradient in the plant family Melastomataceae. J. Trop. Ecol. 34: 204-208. doi: 10.1017/s0266467418000172

Khorsand Rosa, R., Oberbauer, S.F., Starr, G., Parker La Puma, I., Pop, E., Ahlquist, L., and Baldwin, T. 2015. Plant phenological responses to a long-term experimental extension of growing season and soil warming in the tussock tundra of Alaska. Glob. Chang. Biol. 21: 4520-4532. doi: 10.1111/gcb.13040 PMID: 26183112.

Kitajima, K., Joseph Wright, S., and Westbrook, J.W. 2016. Leaf cellulose density as the key determinant of inter-and intra-specific variation in leaf fracture toughness in a species-rich tropical forest. Interface Focus, 6: 20150100. doi: 10.1098/rsfs.2015.0100. PMID: 27274796.

Knops, J.M.H., and Reinhart, K. 2000. Specific leaf area along a nitrogen fertilization gradient. Am. Midl. Nat. 144(2): 265-272. doi: 10.1674/0003-0031(2000)144[0265:SLAAAN]2.0.CO;2.

Kurokawa, H., and Nakashizuka, T. 2008. Leaf herbivory and decomposability in a Malaysian tropical rain forest. Ecology, 89: 2645-2656. doi: 10.1890/07-1352.1. PMID: 18831185.

Lucas, P.W., Turner, I.M., Dominy, N.J., and Yamashita, N. 2000. Mechanical defences to herbivory. Ann. Bot. 86: 913-920. doi: 10.1006/anbo.2000.1261.

Mack, M.C., Schuur, E.A.G., Bret-Harte, M.S., Shaver, G.R., and Chapin, F.S. 2004. Ecosystem carbon storage in arctic tundra reduced by long-term nutrient fertilization. Nature, 431: 440-443. doi: 10.1038/nature02887. PMID: 15386009.

Massey, F.P., Ennos, A.R., and Hartley, S.E. 2007. Grasses and the resource availability hypothesis: The importance of silica-based defences. J. Ecol. 95(3): 414-424. doi: 10.1111/j.1365-2745.2007.01223.x.

Massey, F.P., and Hartley, S.E. 2009. Physical defences wear you down: progressive and irreversible impacts of silica on insect herbivores. J. Anim. Ecol. 78: 281-291. doi: 10.1111/j.1365-2656.2007.0. PMID: 18771503.

McLaren, J.R., Buckeridge, K.M., van de Weg, M.J., Shaver, G.R., Schimel, J.P., and Gough, L. 2017. Shrub encroachment in Arctic tundra: Betula nana effects on above- and belowground litter decomposition. Ecology, 98: 1361-1376. doi: 10.1002/ecy.1790. PMID: 28263375. 
Messier, J., McGill, B.J., and Lechowicz, M.J. 2010. How do traits vary across ecological scales? A case for trait-based ecology. Ecol. Lett. 13(7): 838-848. doi: 10.1111/j.1461-0248.2010.01476.x. PMID: 20482582.

Metcalfe, D.B., Cherif, M., Jepsen, J.U., Vindstad, O.P.L., Kristensen, J., and Belsing, U. 2019. Ecological stoichiometry and nutrient partitioning in two insect herbivores responsible for large-scale forest disturbance in the Fennoscandian subarctic. Ecol. Entomol. 44: 118-128. doi: 10.1111/een.12679.

Myers-Smith, I.H., Forbes, B.C., Wilmking, M., Hallinger, M., Lantz, T., Blok, D., et al. 2011. Shrub expansion in tundra ecosystems: dynamics, impacts and research priorities. Environ. Res. Lett. 6: 045509. doi: 10.1088/1748-9326/6/ 4/045509.

Myers-Smith, I.H., and Hik, D.S. 2018. Climate warming as a driver of tundra shrubline advance. J. Ecol. 106(2) 547-560. doi: 10.1111/1365-2745.12817.

Myers-Smith, I.H., Thomas, H.J.D., and Bjorkman, A.D. 2019. Plant traits inform predictions of tundra responses to global change. New Phytologist, 221(4): 1742-1748. doi: 10.1111/nph.15592

Nichols-Orians, C.M. 1991. Environmentally induced differences in plant traits: Consequences for susceptibility to a leaf-cutter ant. Ecology, 72(5): 1609-1623. doi: 10.2307/1940961

Niittynen, P., Heikkinen, R.K., and Luoto, M. 2020. Decreasing snow cover alters functional composition and diversity of Arctic tundra. Proc. Natl. Acad. Sci. USA, 117: 21480-21487. doi: 10.1073/pnas.2001254117 PMID: 32778575.

Onoda, Y., Westoby, M., Adler, P.B., Choong, A.M.F., Clissold, F.J., Cornelissen, J.H.C., et al. 2011. Global patterns of leaf mechanical properties. Ecol. Lett. 14: 301-312. doi: 10.1111/j.1461-0248.2010.01582.x PMID: 21265976.

Parker, T.C., Tang, J., Clark, M.B., Moody, M.M., and Fetcher, N. 2017. Ecotypic differences in the phenology of the tundra species Eriophorum vaginatum reflect sites of origin. Ecol. Evol. 7(22): 9775-9786. doi: 10.1002/ece3.3445. PMID: 29188008.

Pérez-Harguindeguy, N., Díaz, S., Cornelissen, J.H.C., Vendramini, F., Cabido, M., and Castellanos, A. 2000. Chemistry and toughness predict leaf litter decomposition rates over a wide spectrum of functional types and taxa in central Argentina. Plant Soil. 218: 21-30. doi: 10.1023/a:1014981715532

R Development Core Team. 2016. R: A Language and Environment for Statistical Computing. Version 3.3.2.

Read, J., and Stokes, A. 2006. Plant biomechanics in an ecological context. Am. J. Bot. 93 (10): 1546-1565. doi: 10.3732/ ajb.93.10.1546. PMID: 21642101.

SAS Institute Inc. 2019. JMP ${ }^{\circledR}$, Version 14.3. Cary, NC.

Sanson, G. 2006. The biomechanics of browsing and grazing. Am. J. Bot. 93: 1531-1545. doi: 10.3732/ajb.93.10.1531. PMID: 21642100

Sanson, G., Read, J., Aranwela, N., Clissold, F., and Peeters, P. 2001. Measurement of leaf biomechanical properties in studies of herbivory: Opportunities., problems and procedures. Austral Ecol. 26: 535-546. doi: 10.1046/j.14429993.2001.01154.x.

Schmidt, I.K., Jonasson, S., Shaver, G.R., Michelsen, A., and Nordin, A. 2002. Mineralization and distribution of nutrients in plants and microbes in four arctic ecosystems: Responses to warming. Plant Soil 242: 93-106. doi: 10.1023/A:1019642007929.

Shaver, G.R., and Chapin, F.S., III. 1980. Response to fertilization by various plant growth forms in an Alaskan tundra: Nutrient accumulation and growth. Ecology, 61: 662-675. doi: 10.2307/1937432.

Shaver, G.R., and Chapin, F.S., III. 1991. Production: biomass relationships and element cycling in contrasting arctic vegetation types. Ecol. Monogr. 61(1): 1-23. doi: 10.2307/1942997.

Shaver, G., Fetcher, N., and Chapin, F.S., III. 1986. Growth and flowering in Eriophorum vaginatum: Annual and latitudinal variation. Ecology,67(6): 1524-1535. doi: 10.2307/1939083.

Siefert, A., Violle, C., Chalmandrier, L., Albert, C.H., Taudiere, A., Fajardo, A., et al. 2015. A global meta-analysis of the relative extent of intraspecific trait variation in plant communities. Ecol. Lett. 18: 1406-1419. doi: 10.1111/ ele.12508. PMID: 26415616.

SNAP (Scenarios Network for Alaska and Arctic Planning). 2018. International Arctic Research Center, University of Alaska, Fairbanks. Available from https://snap.uaf.edu/data [accessed 02 Mar 2018].

Tape, K.E.N., Sturm, M., and Racine, C. 2006. The evidence for shrub expansion in Northern Alaska and the PanArctic. Glob. Chang. Biol. 12: 686-702. doi: 10.1111/j.1365-2486.2006.01128.x.

Umaña, M.N., and Swenson, N.G. 2019. Does trait variation within broadly distributed species mirror patterns across species? A case study in Puerto Rico. Ecology, 100: e02745 doi: 10.1002/ecy.2745. PMID: 31032887.

Vincent J.F.V. 1992. Plants. In Biomechanics - Materials: A Practical Approach. Edited by J. F. V. Vincent. Oxford University Press, Oxford. pp. 165-191.

Wein, R.W.1973. Biological flora of British Isles - Eriophorum vaginatum L. J. Ecol. 61(2): 601-615. doi: 10.2307/2259047.

White, R.G., and Trudell, J. 1980. Habitat preference and forage consumption by reindeer and caribou near Atkasook, Alaska. Arct. Alp. Res. 12: 511-529. doi: 10.1080/00040851.1980.12004210.

Wookey, P.A., Aerts, R., Bardgett, R.D., Baptist, F., Bråthen, K., Cornelissen, J.H.C., et al. 2009. Ecosystem feedbacks and cascade processes: Understanding their role in the responses of Arctic and alpine ecosystems to environmental change. Glob. Chang. Biol. 15: 1153-1172. doi: 10.1111/j.1365-2486.2008.01801.x.

Wright, I.J., Reich, P.B., Westoby, M., Ackerly, D.D., Baruch, Z., Bongers, F., et al. 2004. The worldwide leaf economics spectrum. Nature, 428: 821-827. doi: 10.1038/nature02403. PMID: 15103368. 